\title{
Review Article \\ Emerging Photovoltaics: Organic, Copper Zinc Tin Sulphide, and Perovskite-Based Solar Cells
}

\author{
Shraavya Rao, ${ }^{1}$ Ankita Morankar, ${ }^{1}$ Himani Verma, ${ }^{1}$ and Prerna Goswami ${ }^{2}$ \\ ${ }^{1}$ Chemical Engineering Department, Institute of Chemical Technology, Matunga, Mumbai 400019, India \\ ${ }^{2}$ General Engineering Department, Institute of Chemical Technology, Matunga, Mumbai 400019, India
}

Correspondence should be addressed to Shraavya Rao; shraavyar@gmail.com

Received 10 April 2016; Revised 27 July 2016; Accepted 9 August 2016

Academic Editor: Junsheng Yu

Copyright (C) 2016 Shraavya Rao et al. This is an open access article distributed under the Creative Commons Attribution License, which permits unrestricted use, distribution, and reproduction in any medium, provided the original work is properly cited.

As the photovoltaics industry continues to grow rapidly, materials other than silicon are being explored. The aim is to develop technologies that use environmentally friendly, abundant materials, low-cost manufacturing processes without compromising on efficiencies and lifetimes. This paper discusses three of the emerging technologies, organic, copper zinc tin sulphide (CZTS), and perovskite-based solar cells, their advantages, and the possible challenges in making these technologies commercially available.

\section{Introduction}

Solar cells are traditionally classified into first-generation, second-generation, and third-generation solar cells. The firstgeneration cells are based mainly on silicon wafers, the commercially predominant technology. The first crystalline solar cells were fabricated at Bell Laboratory, achieving $4.5 \%$ efficiency in 1953. In 1954, an efficiency of about $6 \%$ was achieved. Over the next decade, efficiencies of around $15 \%$ were achieved. Since then, the efficiency of these cells has risen to over 20\% [1]. Crystalline silicon technology accounted for about $90 \%$ of solar cell production, in 2008 [2]. Currently silicon is used extensively in solar cell devices, even though silicon has many limitations. The extensive use of silicon can be attributed to the fact that silicon technology was highly developed at the time of development of photovoltaic devices. Silicon, being widely available and relatively inexpensive, currently dominates the market. However, the manufacturing of silicon in bulk is an energyintensive process and leads to higher costs. Also, due to the mechanical fragility of silicon, a sheet of strong glass is required to provide mechanical support, further increasing costs. However, given the abundance of silicon, its relatively high efficiencies, the well-developed material and device technology, our understanding of the physics involved, and the long term stability of silicon devices, it seems likely that crystalline silicon will dominate the market for a long time.
The second-generation cells are less material-intensive and avoid use of silicon wafers. Due to lower material consumption, they have lower manufacturing costs. They have lower efficiencies than first-generation cells. They include devices based on amorphous silicon, $\mathrm{CdTe}$, and $\mathrm{Cu}(\mathrm{In}, \mathrm{Ga}) \mathrm{Se}_{2}$ (CIGS). However, these cells have several shortcomings. Typically, their efficiencies are much lower than conventional silicon-based cells. CdTe panels in commercial use currently achieve about $10 \%$. Other shortcomings include the use of relatively rarer elements, such as $\mathrm{Te}$ in $\mathrm{CdTe}$ solar cells. In comparison, CIGS cells have efficiencies similar to that of silicon cells [3]. CIGS and CdTe are the only thin film technologies that have seen commercial success. As the global photovoltaic (PV) market continues to grow, the focus is on developing technologies that use environmentally friendly, abundant materials, low-cost manufacturing processes without compromising on efficiencies and lifetimes. These "thirdgeneration" technologies still require further study and research before they can be made available commercially. These technologies include organic solar cells, perovskite solar cells, and copper zinc tin sulphide (CZTS) solar cells. In particular, perovskite solar cells have attracted a lot of attention as their efficiencies have gone over 20\% [4].

In this paper, we have presented a basic overview of some of the most promising new developments in this field. The paper will concentrate on organic, CZTS, and perovskite materials. The paper discusses these materials, the possibility 


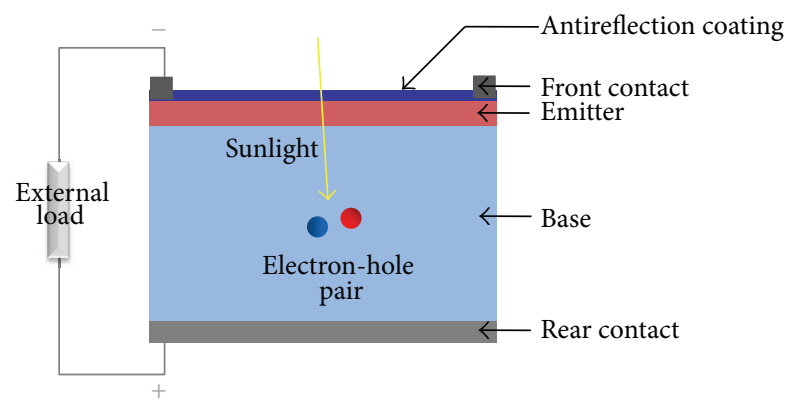

FIgURE 1: Cross section of a typical crystalline silicon solar cell [5].

of low-cost processing, and their performances. It examines the commercial viability of these technologies. We have also discussed the probability of the large-scale manufacture of these devices and the various processing techniques.

\section{General Structure of Solar Cell Devices}

The photovoltaic effect is a process in which an electric voltage is developed at the junction between two dissimilar materials upon illumination. The most common application of the photovoltaic effect is in solar cells, where sunlight is converted into electricity. Practically, almost all solar cells consist of semiconductor materials and incorporate a $\mathrm{p}-\mathrm{n}$ junction. A cross section of a typical crystalline silicon solar cell is shown in Figure 1.

The material used in the solar cell must have the capacity to absorb a large portion of the solar radiation spectrum. Based on the absorption coefficient of the material, light is absorbed, close to the surface of the cell. The absorption of photons from sunlight leads to the generation of electronhole pairs. If these electron-hole pairs reach the p-n junction, the carriers are separated due to the electric field present at the junction. In most solar cells, the generation of charge carriers occurs close to the surface.

The material used in the solar cell must, preferably, be highly crystalline. Also, a semiconductor can give good efficiency of photon absorption only if the energy of the photon is close to the band gap. The material must also have high absorption coefficient, indicating good absorption of light. This is the general structure in silicon-based devices. However, as interest in photovoltaics research continues to grow, modifications have been made for better performance. The general device structure for each material will be discussed separately.

\section{Organic Solar Cell}

The photovoltaic effect in organic materials had been described as far back as the late 1950s by Melvin Calvin. Photoconductivity in organic molecules was first observed in anthracene, 1906. In the late 1950s and 1960s, when crystalline solar cells were proved to be commercially viable, scientific interest in photoconductivity and related subjects spiked, and the potential of organic molecules was studied. In the early 1960s, the semiconducting properties of many organic dyes were discovered and the photovoltaic effect was later observed in these dyes. Also, many biological molecules such as carotenes and porphyrins exhibited the same effect. In spite of this, organic photovoltaic devices never reached the commercial popularity of crystalline solar cells [11]. Much work was carried out in this field during the 1970s, 1980s decades. The oldest, simplest form of organic solar cells was based on a single active layer structure, with an organic film sandwiched between two metal electrodes of differing work functions. Generally, the power conversion efficiencies were usually less than $0.01 \%$ [12]. In 1986, Tang introduced the concept of a bilayer architecture, in which two organic materials, one acting as an electron donor and the other as an electron acceptor, were sandwiched between the electrodes. The resulting device exhibited improved efficiencies of about $1 \%$ [12]. For many years following this development, efficiencies remained limited to about $1 \%$. The last two decades have seen a large amount of work dedicated to an improved understanding of the transport mechanisms in organic devices. The introduction of conjugated polymers led to increased interest in organic photovoltaic devices, and photovoltaic cells were based on these new materials. The concept of a tandem cell structure was introduced later. Lately, the emphasis has shifted to using simple, novel techniques for optimization and improving power conversion efficiencies. These techniques include proper choice of solvents and thermal treatment of solution processed polymer cells [13]. Efficiencies have gone up to around $10 \%$ in recent years, which is the threshold efficiency for commercial applications [9]. Efficiencies of around $8 \%$ have been achieved by solution processed polythiophene-fullerene cells, by the use of novel optimization techniques [12]. Efficiencies of 9.2\% have been achieved by polymer-based devices, as shown by $\mathrm{He}$ et al. [14].

Organic semiconductors have the ability to absorb light from the solar spectrum and give rise to current due to the presence of a large conjugated system. $\mathrm{p}_{\mathrm{z}}$ orbitals electrons undergo delocalization and form $\pi$ bonds with neighbouring $\mathrm{p}_{\mathrm{z}}$ electrons, leading to a conjugated system with alternated single and double bonds. Organic semiconductors usually have poor charge carrier mobility, generally orders of magnitude lower than their inorganic counterparts. This has to be taken into consideration while designing organic photovoltaic (OPV) devices. Another factor to be considered is that unlike crystalline inorganic semiconductors, the exciton (electron-hole pairs bound together by electrostatic interactions) diffusion length in organic materials is relatively shorter, due to their more amorphous and disordered structure. However, the relatively higher absorption coefficients $\left(>10^{5} \mathrm{~cm}^{-1}\right)$ partially make up for the poor mobilities and give good absorption even with thicknesses of around $100 \mathrm{~nm}$. Due to the above features, OPV devices generally have layer thicknesses of around $100 \mathrm{~nm}$ [12].

3.1. Mechanism. The mechanism of organic solar cell involves the generation of electron-hole pairs, as opposed to free charges. Let us consider a bilayer solar cell, in which two active organic materials, namely, a donor and an acceptor, are placed between two electrodes. At least one electrode must be transparent to allow light to enter [12]. 


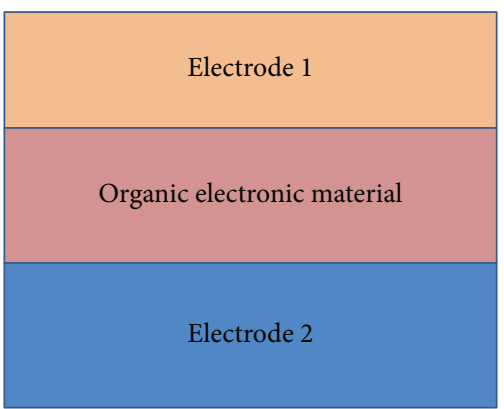

(a)

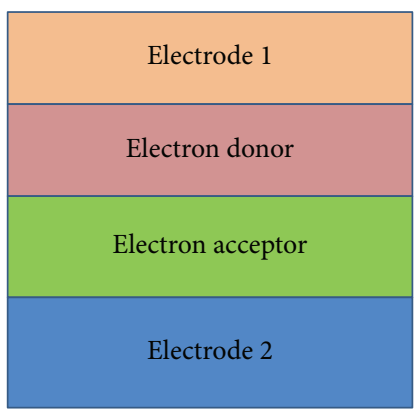

(b)

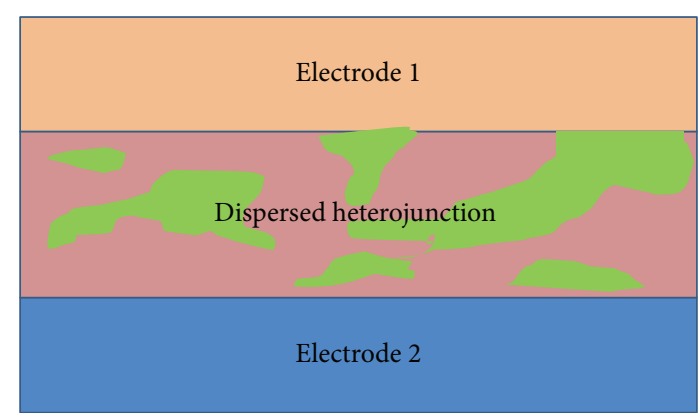

(c)

FIGURE 2: Schematics of different OPV cell structures: (a) single layer device, (b) bilayer device, and (c) bulk heterojunction device.

The process involves the following:

(i) Generation of excitons.

(ii) Exciton diffusion.

(iii) Exciton dissociation.

(iv) Charge transport.

The first step involves the absorption of photons from light and generation of electron-hole pair (exciton). Organic semiconductors have high absorption coefficients. Therefore a layer of thickness in the range of a few hundred nanometres is sufficient to absorb the incident light. The absorbed light triggers the generation of electron-hole pairs. This is followed by exciton diffusion. The excitons thus generated generally have lifetimes in the range of few picoseconds, which limits their mobility. The mobility of excitons is limited to a range of $10 \mathrm{~nm}$. This is called exciton diffusion length and is crucial in the design and performance of organic solar cells. The exciton thus generated undergoes dissociation. The electrostatically coupled electron-hole pair splits into free charges at the donor-acceptor interface. Ideally, all the photogenerated excitons should reach a dissociation length. However, this does not occur due to small exciton diffusion length, limiting the efficiency of the cell. In the charge transport step, the free charges thus produced travel to the electrodes through the donor/acceptor materials, from where they enter the external circuit $[12,36]$.

3.2. Device Structures. The common basic OPV cell structures include the following.

3.2.1. Single Active Layer Cells. Figure 2(a) illustrates the device structure of a single active layer cell. Here, a thin film of organic semiconductor is sandwiched between two electrodes. A layer of high work function (e.g., Indium Titanium Oxide (ITO)) and a layer having low work function ( $\mathrm{Mg}, \mathrm{Ag}$, etc.) are used as electrodes. In practice, these cells have very low efficiencies (quantum efficiencies $<1 \%$ and power conversion efficiencies $<0.1 \%$ ) and do not work very well $[12,36]$.

3.2.2. Bilayer Cells. Two organic materials, one acting as a donor and the second as an acceptor, are sandwiched between two electrodes (as shown in Figure 2(b)). Higher efficiency of exciton dissociation makes these devices more efficient than single layer devices. These devices have achieved power conversion efficiencies of around $3.6 \%$ using copper phthalocyanine and $\mathrm{C}_{60}[12,36]$.

3.2.3. Bulk Heterojunction. Donor and acceptor materials are mixed to form a bulk heterojunction. Figure 2(c) shows structure of the bulk heterojunction. Bulk heterojunction materials have many favourable properties including high photosensitivity and energy conversion efficiency. The presence of illumination induces transfer of electrons from donor-type semiconducting conjugated polymer to acceptortype conjugated polymers or molecules like Buckminsterfullerene, $\mathrm{C}_{60}$. Power conversion efficiencies of above $3.5 \%$ have been achieved using solution-cast P3HT:PCBM blends $[12,36]$.

3.2.4. Diffuse Bilayer Heterojunction. This device structure aims to adapt the advantages of both the bilayer and bulk heterojunction devices. It provides a larger donor-acceptor interface area and a spatially uninterrupted pathway for charge carriers [12].

3.3. Preparation of Organic Solar Cell Materials. Two of the commonly used techniques for materials synthesis are evaporation and solution processing. The choice of techniques depends upon the material to be used. Thermal stability of the material has to be considered while using evaporation techniques. Similarly, solubility of material is required for solution processing. The processing has significantly lower costs as compared to inorganic materials and offers a great deal of versatility $[12,36]$.

Polymer solar cells are usually fabricated by solution processing at low temperatures, as polymer molecules may degrade at high temperatures. Conjugated semiconducting polymers are fabricated by printing and coating techniques such as spin-coating, screen printing, and doctor blading. In general, solution processes are preferred to vacuum processes due to its lower energy requirements and cost effectiveness [12].

3.4. Potential Materials for Organic Solar Cells. In organic solar cells, a layer of organic material, acting as active layer, is sandwiched between two electrodes. The organic 


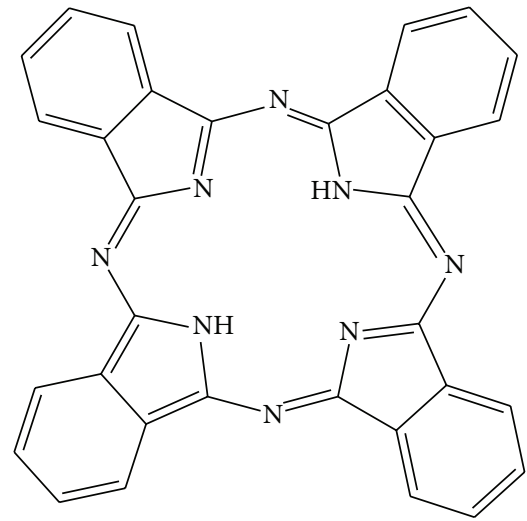

(a) Phthalocyanine

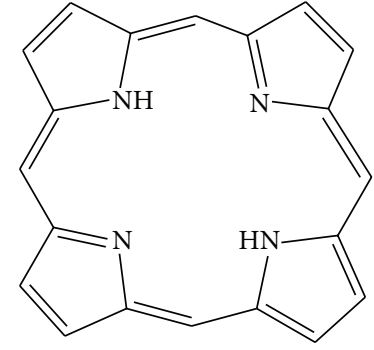

(b) Porphyrin

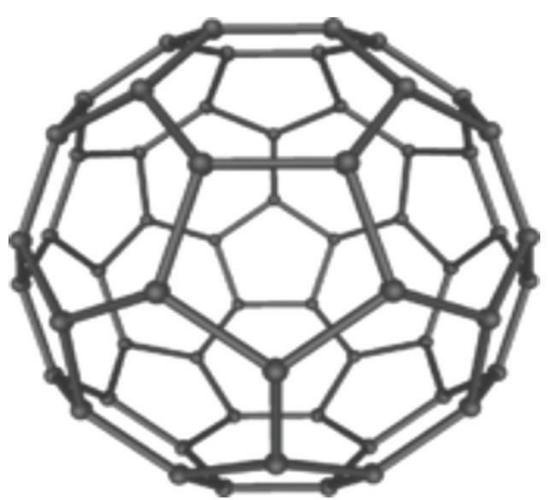

(c) Fullerene [6]<smiles>Cc1ccc(-c2ccc(-c3ccc(-c4ccc(-c5ccc(-c6ccc(C)s6)s5)s4)s3)s2)s1</smiles>

(d) Polythiophene [7]<smiles>O=C1NC(=O)c2ccccc21</smiles>

(e) Phthalimide [8]

FIGURE 3: Organic molecules used as electron donors and electron acceptors in organic solar cells.

semiconductor must be either an electron donor or an electron acceptor material. The active layer consists of both electron donor and electron acceptor material [12].

3.4.1. Electron Donor Materials. Phthalocyanines (Figure 3(a)) and their homologues have been commonly used as electron donor materials. Phthalocyanines $(\mathrm{Pc})$ as shown in Figure 3(a) are 2D 18 pi electron aromatic porphyrin synthetic analogues, in which four isoindole units are joined by $\mathrm{N}$ atoms. Also, copper phthalocyanine and zinc phthalocyanine have been used as donor materials. Double heterojunction $\mathrm{CuPc} / \mathrm{C}_{60}$ thin film cells with $\mathrm{Ag}$ cathode have given efficiencies of about 4\% [37, 38]. Further work on the same $\mathrm{CuPc} / \mathrm{C}_{60}$ cell with hybrid planar-mixed molecular heterojunctions has given efficiencies of around 5.5\% [12, 14, 36-40]. Subphthalocyanines, the lowest homologues of phthalocyanines, have shown promise due to their chemistry and properties. $\mathrm{CuPc} / \mathrm{C}_{60}$ based cells have given greater $V_{\text {oc }}$ as compared to $\mathrm{CuPc} / \mathrm{C}_{60}$ based cells, thus increasing efficiency [41]. Porphyrins (Figure 3(b)) and their derivatives have also been used as electron donors [12, 14, 36-40]. These oligomer organic materials are, however, not always compatible with the flexible electronics. Most of them cannot be obtained through solution processing and require thermal evaporation techniques, leading to increase in cost $[12,14,36-$ 38]. Polymer-based organic solar cells can be obtained via solution processing, thus making them compatible with the flexible substrate and also reducing costs [42].

Polythiophene (Figure 3(d)) derivatives and fullerene (Figure 3(c)) derivatives have been blended together to form bulk heterojunction structures. Poly(3-alkylthiophene)s (P3AT), in particular, have shown great promise as electron donor materials. P3HT has given the best results. P3HT:PCBM ([6,6]-phenyl $\mathrm{C}_{61}$-butyric acid methyl ester) based devices have given efficiencies of around 5\% [40, 42, 43]. Benzodithiophene derivatives have shown great promise for use in PSC and related areas. Benzo(1,2-b, 4,5$\mathrm{b}^{\prime}$ )dithiophene (BDT) has great potential for use in PSCs. $V_{\text {oc }}$ (open circuit voltage) and Jsc. (short circuit current) of BDT derivatives were $0.75 \mathrm{~V}$ and $3.8 \mathrm{~mA} / \mathrm{cm}^{2}$, respectively, corresponding to a PCE of $1.6 \%$, which indicates that $\mathrm{BDT}$ is a promising common unit of photovoltaic conjugated polymers [43].

Recently, phthalimide (Figure 3(e)) has emerged as an attractive candidate for electron-accepting unit in the donoracceptor (D-A) copolymers due to its extremely facile synthesis and readily varied substitution at the imide nitrogen, allowing manipulation of polymer solubility, packing, 
Table 1: Power conversion efficiencies of some organic solar cells.

\begin{tabular}{|c|c|c|c|c|c|}
\hline Device configuration & $\begin{array}{l}J_{\text {sc }} \text { (short circuit } \\
\text { current) in } \mathrm{mA} \mathrm{cm}^{-2}\end{array}$ & $\begin{array}{l}V_{\text {oc }} \text { (open circuit } \\
\text { voltage) in V }\end{array}$ & Fill factor & PCE (\%) & Ref \\
\hline ITO/PFN/PTB7:PC $\mathrm{P}_{71} \mathrm{BM} \mathrm{MoO}_{3} / \mathrm{Al}$ & 17.5 & 0.75 & 0.70 & 9.2 & [14] \\
\hline ITO/ZnO-PVP/PDTS-TPD:PC ${ }_{71} \mathrm{BM} / \mathrm{MoO}_{3} / \mathrm{Ag}$ & 14.4 & 0.86 & 0.69 & 8.5 & [15] \\
\hline ITO/TiPD/PBDTTTC:PC ${ }_{71} \mathrm{BM} / \mathrm{MoO}_{3} / \mathrm{Ag}$ & 16.3 & 0.70 & 0.65 & 7.4 & [16] \\
\hline ITO/PEDOT:PSS/PBnDTDTffBT:PC ${ }_{61} \mathrm{BM} / \mathrm{Ca} / \mathrm{Al}$ & 12.9 & 0.91 & 0.61 & 7.2 & [17] \\
\hline ITO/PEDOT:PSS/PIDT-phanQ:PC $\mathrm{PC}_{71} \mathrm{BM} / \mathrm{C}_{60}$-bis/Ag & 11.5 & 0.88 & 0.61 & 6.2 & [18] \\
\hline
\end{tabular}

and morphology. Two new D-A copolymers, PDTSPh and PDTSBTPh based on dithienosilole donor unit and phthalimide acceptor unit, were synthesized. The power conversion efficiency of the polymer solar cells based on PDTSBTPh:PC ${ }_{70} \mathrm{BM}(1: 2, \mathrm{w} / \mathrm{w})$ reached $2.1 \%$ [44].

3.4.2. Electron Acceptor Materials. Fullerenes (Figure 3(c)) and their derivatives are the most commonly used acceptor materials. Fullerene can be reversibly reduced with up to 6 electrons, which has led to it being commonly used as an electron acceptor. $\mathrm{C}_{60}$ has limited solubility in most organic solvents. To increase the solubility and to avoid severe phase separation of D/A blend, [6,6]-phenyl $\mathrm{C}_{60}$ butyric acid methyl ester (PC60BM) has been used, as it can be solution processed. The PC70BM derivative has also been studied, but though it has stronger absorption in the visible range, it is more expensive than $\mathrm{C}_{60}$ due to the purification processes [12, 14, 36-39]. Indene-fullerenes have also been used as electron acceptor materials, specifically indene-fullerene bisadduct (ICBA) and indene-fullerene monoadduct (ICMA). These can be synthesized easily via a one-pot reaction. ICBA/P3HT and ICMA/P3HT have given higher $V_{\text {oc }}$ than P3HT/PCBM devices [12, 14]. Lately, $\mathrm{C}_{60}$ derivatives with oligo(phenyleneethynediyl) (OPE) subunits have been studied [45].

SubPc has also been used an acceptor material. Tetracene as a donor and SubPc as an acceptor have been used and efficiencies have reached $2.9 \%$. Fluorinated subphthalocyanine $\left(\mathrm{F}_{16} \mathrm{SubPc}\right)$ also shows potential as electron donor [12].

Table 1 gives a few materials and their efficiencies along with the device type in an organic solar cell. The highest efficiency for organic solar cells is around $11 \%$ (Toshiba) [31].

\section{CZTS Solar Cells}

The thin film solar cell technology is growing in both capacity and market share. Currently, it accounts for around $20 \%$ of the PV market [46]. CdTe solar cells account for about 10\% and the remainder is divided between thin film silicon and $\mathrm{Cu}(\mathrm{In}, \mathrm{Ga}) \mathrm{Se}_{2}$ (CIGS) where CIGS is growing rapidly. The main advantage for CIGS solar cells is the high efficiency, which has currently crossed $20 \%$. Currently, the best thin film solar cells have above $20 \%$ efficiency and are based on CIGS [46-49].

Recently, quaternary compound $\mathrm{Cu}_{2} \mathrm{ZnSn}(\mathrm{S} / \mathrm{Se})_{4}$ has been studied as a potential photovoltaic material, due to its similarities with CIGS $\left(\mathrm{Cu}(\mathrm{In}, \mathrm{Ga}) \mathrm{Se}_{2}\right)$ in material properties and the relative availability of raw materials. CZTS is

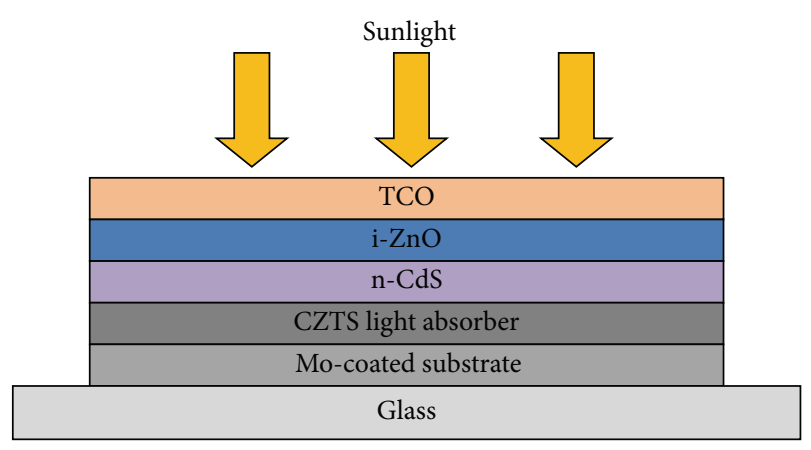

Figure 4: Structure of CZTS solar cell [9].

a compound semiconductor in the form $(\mathrm{I})_{2}(\mathrm{II})(\mathrm{IV})(\mathrm{VI})_{4}$. It possesses a relatively high absorption coefficient $\left(>10^{4} \mathrm{~cm}^{-1}\right)$ and a band gap of around $1.45 \mathrm{eV}$ [47]. Theoretically, efficiencies of around 32\% have been calculated for CZTS thin film solar cells having a layer of CZTS several micrometers thick [46-49].

4.1. Basic Structure. Schematic diagram of CZTS solar cell structure is shown in Figure 4. Molybdenum thin film having thickness of $500-700 \mathrm{~nm}$ is deposited on glass substrate and acts as a back contact. Molybdenum has high stability in harsh reactive conditions such as sulphur-containing vapor and high temperatures. The absorber layer, $p$-type CZTS thin film is deposited on Mo layer, having thickness in the range of 1-2 micrometers. To form a p-n junction, CdS layer having thickness of $50-100 \mathrm{~nm}$ is coated on CZTS layer. The CZTS surface is uneven and cannot be completely covered by CdS thin film. This may cause shorting between the front and back contacts. To avoid leakage, $50-90 \mathrm{~nm}$ intrinsic $\mathrm{ZnO}$ thin film is coated on CdS layer. Then transparent conducting oxide thin film is deposited and acts as the front contact [47, 48].

\subsection{Fabrication of CZTS Devices}

4.2.1. Vacuum Techniques. All the elements are simultaneously incorporated in a single step, in one-step vacuum processes. These techniques include cosputtering and coevaporation, both of which give devices with good performance [48]. Pulsed-laser deposition is a two-step process wherein the first step incorporates the precursors in an ambient-temperature process like sputtering or evaporation. This is followed by annealing. The incorporation of chalcogens can occur in either step $[47,48]$. 
TABLE 2: Comparison of CZTS cells fabricated by different processes.

\begin{tabular}{|c|c|c|c|}
\hline Method & Precursor & Efficiency (\%) & Comments \\
\hline $\begin{array}{l}\text { Vacuum thermal } \\
\text { evaporation }\end{array}$ & $\mathrm{Cu}, \mathrm{Zn}, \mathrm{Sn}, \mathrm{S}$ & $8.4[19]$ & $\begin{array}{l}\text { Has been used commercially, fast process compared to } \\
\text { sputtering, better purity, high energy requirements to } \\
\text { create vacuum, difficulties in scaling up, thickness } \\
\text { control may be problematic }\end{array}$ \\
\hline Sputtering & $\mathrm{Cu}, \mathrm{SnS}, \mathrm{ZnS}$ & $6.77[20]$ & $\begin{array}{l}\text { Slower than evaporation, scaling up is easier, higher } \\
\text { capital costs, accounts for significant part of } \\
\text { commercial production of CIGS cells, vacuum process } \\
\text { leading to higher energy requirements, cost-effective }\end{array}$ \\
\hline Electrodeposition & $\begin{array}{l}\mathrm{Cu}(\mathrm{II}) \text { ion, } \mathrm{Zn}(\mathrm{II}) \text { ion, } \\
\quad \mathrm{Sn}(\mathrm{IV}) \text { ion }\end{array}$ & $7.3[21]$ & $\begin{array}{l}\text { Generally more environmentally friendly, usually } \\
\text { nontoxic; for copper, zinc, tin, electrodeposition is } \\
\text { carried out at room temperature, reducing energy } \\
\text { requirements; has been commercially used; thickness } \\
\text { control may be problematic }\end{array}$ \\
\hline Sol-gel based method & $\begin{array}{l}\text { Copper (II) acetate } \\
\text { monohydrate } \\
\text { Zinc (II) acetate dehydrate } \\
\text { Tin (II) chloride dehydrate }\end{array}$ & $2.23[22]$ & $\begin{array}{l}\text { Simple and versatile, cost-effective, environmentally } \\
\text { friendly due to lower temperatures }\end{array}$ \\
\hline Pulsed laser deposition & $\begin{array}{l}\text { In-house fabricated CZTS } \\
\text { pellet }\end{array}$ & $3.14[23]$ & $\begin{array}{l}\text { Vacuum process, higher energy requirements, scaling } \\
\text { up difficulties, composition and thickness dependence } \\
\text { on deposition conditions not yet well understood }\end{array}$ \\
\hline
\end{tabular}

4.2.2. Nonvacuum Techniques. These processes include electrodeposition, sol-gel based methods, and spray coating. They are scalable and cheaper, which makes them suitable for large-scale processes. The highest efficiency of CZTSSe cell $(12.6 \%)$ has been achieved by nonvacuum techniques: simultaneous use of spin-coating solution and particles of constituents. Other promising methods are nanoparticles and electroplating $[47,48]$. Electrochemical deposition also appears to be a promising preparation method [47]. Table 2 shows a comparison of some of the processing techniques.

\section{Perovskites}

Perovskites are materials described by the formula $\mathrm{ABX}_{3}$, where $\mathrm{A}, \mathrm{B}$ are cations, $\mathrm{A}$ is bigger than $\mathrm{B}$, and $\mathrm{X}$ is an anion. Their structure is similar to the structure of calcium titanate. Figure 5 shows the crystal structure of a typical perovskite structured compound $\mathrm{CH}_{3} \mathrm{NH}_{3} \mathrm{~Pb}[10]$.

5.1. Hybrid Halide Perovskites. In solar cells, organicinorganic halide perovskites are most commonly used, where $\mathrm{A}$ is an organic cation and $\mathrm{X}$ is a halide, usually Iodine, though $\mathrm{Cl}$ and $\mathrm{Br}$ have also been used. A is usually the methyl ammonium cation $\left(\mathrm{CH}_{3} \mathrm{NH}_{3}{ }^{+}\right)$. However, ethyl ammonium $\left(\mathrm{CH}_{3} \mathrm{CH}_{2} \mathrm{NH}_{3}{ }^{+}\right)$and formamidinium $\left(\mathrm{NH}_{2} \mathrm{CH}=\mathrm{NH}_{2}{ }^{+}\right)$ are also used as cations. $\mathrm{Cl}$ and $\mathrm{Br}$ are typically used in a mixed halide material. $\mathrm{B}$ is usually $\mathrm{Pb}$ or $\mathrm{Sn}$, due to band gap considerations. However, due to the lower stability of $\mathrm{Sn}$ and the relative ease with which it is oxidized to $\mathrm{SnI}_{4}, \mathrm{~Pb}$ is generally preferred. Structure of methyl ammonium lead is shown in Figure 5. Lead has weak tendency to undergo oxidization due to relativistic effects. Therefore, methyl ammonium lead triiodide is generally taken as the standard compound, though mixed halides $\mathrm{CH}_{3} \mathrm{NH}_{3} \mathrm{PbI}_{3-x} \mathrm{Cl}_{x}$ and $\mathrm{CH}_{3} \mathrm{NH}_{3} \mathrm{PbI}_{3-x} \mathrm{Cl}_{x}$ are also considered important. Forma-

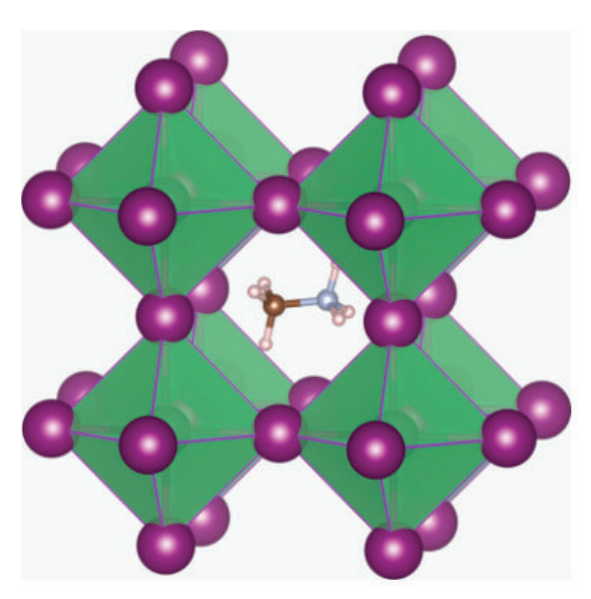

FIGURE 5: Structure of $\mathrm{CH}_{3} \mathrm{NH}_{3} \mathrm{~Pb}$ [10].

midinium lead trihalide $\left(\mathrm{H}_{2} \mathrm{NCHNH}_{2} \mathrm{PbX}_{3}\right)$ has also shown potential, with band gaps in the range of 1.5 to $2.2 \mathrm{eV}[50,51]$.

The perovskite properties have been known for many years. However, perovskite materials were first utilized in a photovoltaic device in 2009. This device was based on a dye-sensitized solar cell architecture, using perovskite as a sensitizer, and achieved an efficiency of $3.8 \%$ for $\mathrm{CH}_{3} \mathrm{NH}_{3} \mathrm{PbI}_{3}$ cells. The main drawback was the cell stability, as the lifetime was in minutes. In 2012, Snaith and his coworkers achieved a breakthrough, with efficiencies going above $10 \%$, and demonstrated that perovskites played a role in the transport of electrons and holes towards the cell terminal, laying the basis for planar cells [52]. Thus far, research in perovskite cells has mainly concentrated on $\mathrm{CH}_{3} \mathrm{NH}_{3} \mathrm{PbI}_{3}$ and $\mathrm{CH}_{3} \mathrm{NH}_{3} \mathrm{PbI}_{3-x} \mathrm{Cl}_{x}$. Currently, high efficiencies over $20 \%$ have been achieved by perovskite devices [30], based on 
TABLE 3: A few representative devices, architecture, fill factors, and their efficiencies.

\begin{tabular}{|c|c|c|c|c|c|c|}
\hline Architecture & Type & HTM & $V_{\text {oc }}(\mathrm{V})$ & $\mathrm{FF}$ & PCE (\%) & Ref \\
\hline $\mathrm{mpTiO}_{2} / \mathrm{MAPbI}_{3} / \mathrm{HTM}$ & MS & Spiro-OMeTAD & 0.99 & 0.73 & 15 & {$[24]$} \\
\hline $\mathrm{Y}: \mathrm{TiO}_{2} / \mathrm{MAPbI}_{3-x} \mathrm{Cl}_{x} / \mathrm{HTM}$ & $\mathrm{P}$ & Spiro-OMeTAD & 1.13 & 0.75 & 19.3 & [25] \\
\hline $\mathrm{mpTiO}_{2} / \mathrm{MAPbI}_{3} / \mathrm{HTM}$ & MS & $\mathrm{CuSCN}$ & 1.01 & 0.62 & 12.4 & {$[26]$} \\
\hline $\mathrm{TiO}_{2} / \mathrm{MAPbI}_{3-x} \mathrm{Cl}_{x} / \mathrm{HTM}$ & $\mathrm{P}$ & $\mathrm{CuSCN}$ & 0.73 & 0.62 & 6.4 & [27] \\
\hline $\mathrm{HTM} / \mathrm{MAPbI}_{3-x} \mathrm{Cl}_{x} / \mathrm{PC}_{61} \mathrm{BM} / \mathrm{ZnO}$ & $\mathrm{P}$ & Graphene oxide & 0.99 & 0.72 & 11.1 & [28] \\
\hline $\mathrm{mpTiO}_{2} / \mathrm{MAPbI}_{3} / \mathrm{HTM}$ & MS & $\mathrm{P} 3 \mathrm{HT}$ & 0.73 & 0.73 & 6.7 & [29] \\
\hline
\end{tabular}

P refers to devices with planar architecture and MS refers to devices with mesoporous architecture.

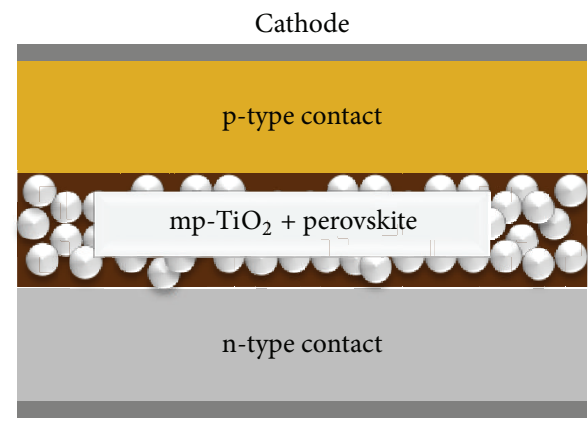

Anode

(a)

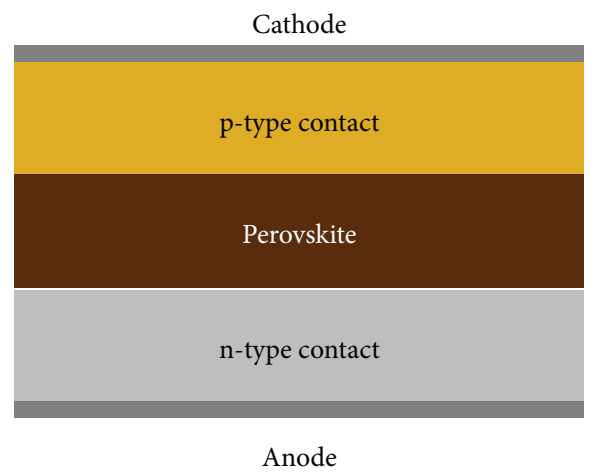

(b)

FIGURE 6: Perovskite device structures with (a) mesoporous architecture and (b) planar architecture.

a mesoporous $\mathrm{TiO}_{2}$ structure. It is expected that higher efficiencies can be possible, utilizing a tandem structure.

5.2. Device Architecture. Perovskite solar cells work efficiently in various architectures, depending on the role played by the perovskite material in the device or the nature of the electrodes. It can broadly be divided into mesoporous nanostructure (similar to dye-sensitized solar cells) (a) or planar structure (thin film) (b) [30,53]. A wide range of techniques are available for the fabrication of devices of either architecture.

5.2.1. Mesoporous Architecture. Initially, the organic-inorganic perovskites were used as sensitizers for liquid-state DSSCs (dye-sensitized solar cells) as nanoparticles on the surface of a mesoporous metal oxide film (Figure 6(a)). When coupled with an iodide-triiodide liquid electrolyte, the cells gave reasonably high PCEs but had poor stability due to the dissolution of the perovskite film. A major breakthrough was made in 2012 by coupling the perovskite with a small organic molecule, $2,2^{\prime} 7,7^{\prime}$-tetrakis(N,N-di-p-methoxy-phenyl-amine)-9, $9^{\prime}$-spirobiflourene (spiro-OMeTAD), which would act as hole transport material (HTM). A PCE of up to $9.7 \%$ was obtained using $\mathrm{CH}_{3} \mathrm{NH}_{3} \mathrm{PbI}_{3}$ devices with a titanium oxide $\left(\mathrm{TiO}_{2}\right)$ scaffold [54]. Transient absorption studies showed that $\mathrm{TiO}_{2}$ plays a role in the photoconversion process. $\mathrm{TiO}_{2}$ is therefore considered an active component in the solar cell. $\mathrm{TiO}_{2}$ along with metal oxides with similar functions is considered active scaffolds. Around the same time, a PCE of $10.9 \%$ was achieved using a mixed halide perovskite $\mathrm{CH}_{3} \mathrm{NH}_{3} \mathrm{PbI}_{3-x} \mathrm{Cl}_{x}$, deposited on insulating
$\mathrm{Al}_{2} \mathrm{O}_{3}$ scaffold and coupled with spiro-OMeTAD. These types of cells are known as meso-superstructured solar cells (MSSCs). The metal oxides in MSSCs act as a scaffold but do not take active part in the charge transport. They are considered to be passive scaffolding [54]. This architecture is based on DSSCs. Perovskite is mainly used for light absorption and other materials are used for the charge transport. The perovskite light absorber forms a coating on the mesoporous scaffolding $[30,53]$.

5.2.2. Planar Heterojunction Architecture. In this architecture (as shown in Figure 6(b)) a semiconducting absorber material is usually sandwiched between two selective contacts, without a mesoporous scaffold. Here, there is a more noticeable interface between layers. Charge-selective transporting or blocking layers can be used in planar devices. This architecture is somewhat similar to thin film solar cells $[30,53,54]$.

Table 3 shows a few representative devices and their architectures and performance.

5.3. Fabrication Techniques. Compared to conventional silicon solar cells, perovskite cells can be manufactured with relatively simpler techniques. Many different techniques are available for synthesizing perovskite active layers, including the following:

(1) One-step precursor solution deposition.

(2) Dual-source vapor deposition.

(3) Vapor assisted solution process.

(4) Sequential vapor deposition. 
TABLE 4: A comparison of common fabrication techniques.

\begin{tabular}{|c|c|c|c|}
\hline Method & Description & Advantages & Disadvantages \\
\hline $\begin{array}{l}\text { One-step solution } \\
\text { deposition }\end{array}$ & $\begin{array}{l}\text { A solution of the organic and } \\
\text { inorganic components dissolved } \\
\text { in a solvent is spin-coated on a } \\
\text { substrate to give perovskite }\end{array}$ & $\begin{array}{l}\text { Cost-effective, straightforward to } \\
\text { implement }\end{array}$ & $\begin{array}{l}\text { Poor film formation leads to limited } \\
\text { efficiency, choice of a solvent that can } \\
\text { simultaneously dissolve both } \\
\text { components is limited, spin-coating is } \\
\text { inherently a batch process, which may } \\
\text { limit production speed }\end{array}$ \\
\hline $\begin{array}{l}\text { Two-step } \\
\text { solution-based } \\
\text { processing }\end{array}$ & $\begin{array}{l}\text { First, a solution of the inorganic } \\
\text { component is spin-coated } \\
\text { followed by spin-coating of a } \\
\text { solution of the organic } \\
\text { component }\end{array}$ & $\begin{array}{l}\text { Better photovoltaic performance } \\
\text { compared to one-step methods }\end{array}$ & $\begin{array}{l}\text { Less control over film thickness as } \\
\text { compared to vacuum processes }\end{array}$ \\
\hline $\begin{array}{l}\text { Dual-source vapor } \\
\text { deposition }\end{array}$ & $\begin{array}{l}\text { The organic and inorganic } \\
\text { components are coevaporated in } \\
\text { an as-deposited ratio; deposition } \\
\text { is followed by thermal annealing }\end{array}$ & $\begin{array}{l}\text { Better film uniformity, as } \\
\text { compared to solution processes } \\
\text { leading to better efficiencies }\end{array}$ & $\begin{array}{l}\text { Vacuum process, which leads to high } \\
\text { energy requirements; difficulties in } \\
\text { simultaneously controlling the } \\
\text { deposition rates of both components, } \\
\text { leading to an undesirable } \\
\text { stoichiometric film }\end{array}$ \\
\hline $\begin{array}{l}\text { Sequential vapor } \\
\text { deposition }\end{array}$ & $\begin{array}{l}\text { A bilayer film of the inorganic } \\
\text { and organic components is } \\
\text { prepared by sequential } \\
\text { deposition; subsequent vacuum } \\
\text { deposition of the organic } \\
\text { component is followed by } \\
\text { thermal annealing }\end{array}$ & $\begin{array}{l}\text { Eliminates problems of one-step } \\
\text { codeposition }\end{array}$ & $\begin{array}{l}\text { Vacuum process, which leads to high } \\
\text { energy requirements, higher costs, } \\
\text { limiting mass production }\end{array}$ \\
\hline $\begin{array}{l}\text { Vapor assisted } \\
\text { solution process }\end{array}$ & $\begin{array}{l}\text { Inorganic component is } \\
\text { deposited by spin-coating } \\
\text { followed by exposure to the } \\
\text { vapor of the organic component } \\
\text { at an elevated temperature }\end{array}$ & $\begin{array}{l}\text { Combination of vapor and } \\
\text { solution-based processes gives } \\
\text { better film quality }\end{array}$ & \\
\hline Electrodeposition & $\begin{array}{l}\text { The inorganic film is } \\
\text { electrochemically deposited } \\
\text { followed by a solid state in situ } \\
\text { reaction with inorganic layer to } \\
\text { give perovskite }\end{array}$ & $\begin{array}{l}\text { Environmentally friendly, usually } \\
\text { nontoxic; has been commercially } \\
\text { used }\end{array}$ & \\
\hline
\end{tabular}

Scaling up of these processes seems to be relatively feasible $[53,55]$.

Perovskites can be easily incorporated into the existing photovoltaic architectures. The best perovskite structures use vacuum deposition to give more uniform film qualities. However this necessitates the accurate coevaporation of the organic and inorganic components simultaneously. This will require specialist evaporation chambers. A much simpler alternative is provided by the development of low temperature solution deposition techniques, which can be carried out with existing material sets. Perovskite solar cells were initially developed out of DSSC research. However, now, many perovskite device architectures are similar to thin film photovoltaics except with perovskite as active layers.

The major issue for practical device fabrication is of the film thickness and quality. The active perovskite layer must be several hundred nanometres thick, much more than for most organic photovoltaics. Even with optimization of deposition conditions and annealing temperature, a significant amount of surface roughness remains, thus requiring the thickness of interface layers to be greater than what might normally be used. However efficiencies of around $11 \%$ have been achieved by spin-coated devices $[46,47,49]$. Table 4 shows a comparison of some of the common fabrication techniques.

\section{Comparison of Organic, CZTS, and Perovskite-Based Devices}

6.1. Performances. The main considerations for successful commercialization of these technologies are efficiencies, costs, and lifetimes. Other factors to be considered include toxic materials used in the manufacturing processes, environmentally friendly production, and the possibility of flexible, aesthetically pleasing products.

Organic solar cells have efficiencies lower than their inorganic counterparts. While improvement is warranted, their low efficiencies are balanced by the fact that they are much cheaper to produce. The highest organic cell efficiency of $11.0 \%$ is claimed by Toshiba, using a p-type semiconductor material and a structure called "inverted structure" [31].

In case of CZTS devices, a world record conversion efficiency of $12.6 \%$ by IBM obtained for $\mathrm{Cu}_{2} \mathrm{ZnSn}(\mathrm{S}, \mathrm{Se})_{4}$ solar cells was made by solution-based method. The method introduced Selenium, a rare element, into the CZTS TFSC. 
TABLE 5: Highest efficiencies of solar cells [30].

\begin{tabular}{|c|c|c|c|c|c|}
\hline Device & Efficiency (\%) & Area $\left(\mathrm{cm}^{2}\right)$ & $\begin{array}{l}V_{\mathrm{oc}}(\mathrm{V}) \mathrm{OC} \\
\text { voltage }\end{array}$ & $\begin{array}{l}J_{\mathrm{sc}} \mathrm{mA} / \mathrm{cm}^{2} \\
\text { short circuit } \\
\text { current }\end{array}$ & Description \\
\hline $\begin{array}{l}\text { Organic thin film (measured } \\
\text { under the global AM } 1.5 \\
\left.\text { spectrum }\left(1000 \mathrm{~W} / \mathrm{m}^{2}\right) \text { at } 25^{\circ} \mathrm{C}\right)\end{array}$ & $11.0 \pm 0.3$ & $0.993(\mathrm{da})$ & 0.793 & 19.40 & Toshiba [31] \\
\hline $\begin{array}{l}\text { Organic (mini module) } \\
\text { (measured under the global AM } \\
1.5 \text { spectrum }\left(1000 \mathrm{~W} / \mathrm{m}^{2}\right) \text { at } \\
25^{\circ} \mathrm{C} \text { ) }\end{array}$ & $9.7 \pm 0.3$ & $26.14(\mathrm{da})$ & 0.686 & 11.47 & $\begin{array}{l}\text { Toshiba } \\
\text { (eight-series } \\
\text { cells) }\end{array}$ \\
\hline $\begin{array}{l}\text { CZTSSe (thin film) (not } \\
\text { measured under the global AM } \\
1.5 \text { spectrum }\left(1000 \mathrm{Wm}^{-2}\right) \text { at } \\
\left.25^{\circ} \mathrm{C}\right)\end{array}$ & $12.6 \pm 0.3$ & 0.4209 (ap) & 0.5134 & 35.21 & $\begin{array}{l}\text { IBM solution } \\
\text { grown [32] }\end{array}$ \\
\hline $\begin{array}{l}\text { CZTS (thin film) (not measured } \\
\text { under the global AM } 1.5 \\
\left.\text { spectrum }\left(1000 \mathrm{Wm}^{-2}\right) \text { at } 25^{\circ} \mathrm{C}\right)\end{array}$ & $9.1 \pm 0.2$ & $0.2409(\mathrm{da})$ & 0.701 & 20.64 & $\begin{array}{l}\text { Toyota Central } \\
\text { R\&D Labs [33] }\end{array}$ \\
\hline $\begin{array}{l}\text { Perovskite (thin film) (not } \\
\text { measured under the global AM } \\
1.5 \text { spectrum }\left(1000 \mathrm{Wm}^{-2}\right) \text { at } \\
25^{\circ} \mathrm{C} \text { ) }\end{array}$ & $20.1 \pm 0.4$ & 0.0955 (ap) & 1.059 & 24.65 & KRICT [34] \\
\hline $\begin{array}{l}\text { Perovskite thin film (measured } \\
\text { under the global AM } 1.5 \\
\left.\text { spectrum }\left(1000 \mathrm{~W} / \mathrm{m}^{2}\right) \text { at } 25^{\circ} \mathrm{C}\right)\end{array}$ & $15.0 \pm 0.6$ & 1.017 (ap) & 1.090 & 20.61 & NIMS [35] \\
\hline
\end{tabular}

da: designated illumination area; ap: aperture area.

However, hydrazine solvent was used, a toxic and instable solvent [55].

The efficiencies of perovskite solar cell devices have increased drastically, from $3.8 \%$ [52] in 2009 to $21.02 \%$ in 2015, thus making it one of the fastest growing emerging PV technologies. Perovskite cells have thus reached efficiencies comparable to multicrystalline silicon and CIGS (efficiencies around 20\%) [55]. The $21.02 \%$ efficiency has been achieved at EPFL. Other perovskite solar cells have also reached comparable efficiencies [52].

The highest efficiencies of these cells are given in Table 5.

6.2. Advantages and Disadvantages. Organic semiconductors promise to be much cheaper than their inorganic counterparts, due to low-cost processing. They show great versatility in production methods, including methods like solution processes and high throughput printing techniques, to name a few. These methods require much less energy and lower temperatures, compared to conventional methods, and reduce the cost drastically. Environmentally friendly, cheaper materials and production are another advantage.

The organic molecule properties can be "tailored" depending upon the applications. This is a very important advantage. Due to tailoring of molecule properties and lowcost versatile production techniques, organic solar cells can be incredibly flexible and lightweight. They can be manufactured in extremely thin, lightweight, flexible, and aesthetically pleasing forms, unlike conventional solar cells. Colourful, semitransparent solar cells are possible. Organic solar cells usually have much lower efficiencies as compared to silicon cells. They usually have a shorter operational lifetime, limited by oxygen and UV radiation. However, lifetimes of OPV devices by Heliatek have been extrapolated to over 20 years (Heliatek). Despite these limitations, organic solar cells show great promise and are gaining rapid acceptance in the solar photovoltaics industries.

CZTS solar cells are mainly being studied as an alternative to CIGS and CdTe devices. CZTS TFSCs have an important advantage over CIGS solar cells. The elements used in CZTS devices, namely, copper, tin, zinc, and sulphur, are nontoxic, environmentally friendly, and abundant. Indium and Gallium, which are used in CIGS devices, are both expensive. The cost of raw materials for CZTS TFSCs is significantly lower than that of the three thin film technologies currently in use, namely, crystal $\mathrm{Si}, \mathrm{CdTe}$, and CIGS. Selenium has been used in CZTS TFSCs along with sulphur, but although it is rarer than Indium or Gallium, it is much cheaper. The CZTS devices can also be manufactured using the vacuum coating techniques used in CIGS devices. Their efficiencies are less sensitive to changes in temperatures, which makes them favourable for higher temperature applications. They also offer longer lifetimes than the other two devices mentioned here.

Efforts are being made to replace Selenium with sulphur. Selenium is not very toxic, but its compounds such as hydrogen selenide are highly toxic. The CZTSSe device currently has higher efficiencies than the CZTS cell [47]. The CZTS device usually incorporates CdS film. The p-type CZTS layer is the absorber and the CdS is used as the n-type. Cd is toxic, and legal restrictions on the use of $\mathrm{Cd}$ in electronic devices could cause problems. Efforts are being made to eliminate the CdS layer from CZTS devices [47]. In addition, 
TABLE 6: Comparison of cost and manufacturing process.

\begin{tabular}{lcccc}
\hline Devices & Cost of raw material & $\begin{array}{c}\text { Cost of } \\
\text { manufacturing }\end{array}$ & Method of manufacturing & Other properties \\
\hline Organic & Low & Low & $\begin{array}{c}\text { Environmentally friendly, } \\
\text { requires low temperature and } \\
\text { energy }\end{array}$ & $\begin{array}{c}\text { Can be tailored according to } \\
\text { application, thin and light } \\
\text { weight, shorter lifetime }\end{array}$ \\
\hline CZTS & Higher than organic & High & Suitable for high temperature \\
applications, efficiency less \\
Perovskite
\end{tabular}

the efficiencies of CZTS devices are still about half that of CZTS and CdTe devices (around 20\%) [30]. However, CZTS technology is still at a much earlier stage of development.

Despite these challenges, due to availability of raw materials and environmentally friendly features, CZTS continues to be a promising avenue of research and is likely to become commercially viable.

The perovskite-based devices have shown unprecedented efficiencies in a very short period. It seems likely that perovskite-based devices will soon overtake the established thin film technologies (CdTe and CIGS). Its advantages over other PV devices include its low temperature solution-based fabrication method leading to lower manufacturing costs, higher stability in air, and higher absorption coefficients. Typically, it gives relatively higher values of $V_{\mathrm{oc}}(>1.1 \mathrm{~V})$. Also, its efficiency is aided by the higher diffusion length and higher mobilities of the charge carriers.

However, the use of lead poses a problem, due to toxicity concerns. Elimination of lead in favour of $\mathrm{Sn}$ is a promising possibility [53]. Also, the sensitivity of perovskites towards moisture necessitates them to be well sealed, to prevent their premature degradation. There is insufficient data regarding lifetimes. The materials undergo degradation under standard conditions and show drop in efficiencies.

Nevertheless, inorganic-organic halide perovskite solar cells have demonstrated great potential due to their high efficiencies and low-cost manufacturing. Since this technology is relatively new, there are many opportunities for further research and study.

Table 6 shows comparison between all the three types of solar cells.

\section{Conclusion}

Many different approaches are being studied to increase the efficiencies of solar cell devices. The photovoltaic materials covered in this paper are still mostly in the research and development stage. However, as the global energy crisis continues, research in solar cells continues to gain traction. With the evolution of material technology over the next few years, the practical implementation of these approaches is likely to become feasible.
Successful commercialization of these technologies depends mainly on three things: cost, efficiency, and lifetime. While organic solar cells have lower efficiencies (currently around 10\%) and shorter lifetimes in comparison to inorganic devices, the versatility they offer in terms of processing and the low-cost manufacturing makes them an attractive prospect. Manufacturing of organic solar cells remains much cheaper and simpler in comparison to inorganic devices. The possibility of manufacturing of colourful, flexible aesthetically pleasing solar cells is also an added advantage [36].

CZTS devices have lower efficiencies in general (around $9 \%$, unless Selenium is incorporated. However, Se, being a rare element, costs more and this could limit its largescale development. However, the elimination of Se in favour of $S$ remains an option. Even so, as technology continues to mature, CZTS appears to be a good alternative to the CIGS solar cell. With the relative abundance of its elements, the environmentally friendly features, and reasonably good performance, CZTS appears to be a promising avenue for further study.

Perovskite solar cells have shown rapid growth in the past 5 years. These devices have shown unprecedented increase in efficiencies, from $9.7 \%$ in 2012 to around $20 \%$ currently, and have become comparable with thin film technologies like CIGS and CdTe. As yet, the working principle behind the perovskite photovoltaic devices has not yet been established. Perovskite cells offer a diverse range of production methods and the possibility of manufacturing aesthetically pleasing solar cells. Currently, the use of lead in these devices is not an obstacle to large-scale applications. However, as the use of toxic materials is likely to become increasingly restricted, replacement of lead with tin is being studied [53]. As interest in perovskite-based technology continues to grow, commercialization of this technology seems very likely.

To summarize, this article provides a basic understanding of principle of a solar cell and an overview of various developments in this field over the last few decades. It gives a comparison of the fabrication techniques for various devices. In particular, it presents a review of the progress in development of solar cells of third generation and compares their efficiency, cost effectiveness, and also their future commercial prospects. 


\section{Competing Interests}

The authors declare that there is no conflict of interests regarding the publication of this paper.

\section{References}

[1] M. A. Green, "The path to $25 \%$ silicon solar cell efficiency: history of silicon cell evolution," Progress in Photovoltaics: Research and Applications, vol. 17, no. 3, pp. 183-189, 2009.

[2] T. Saga, "Advances in crystalline silicon solar cell technology for industrial mass production," NPG Asia Materials, vol. 2, no. 3, pp. 96-102, 2010.

[3] S. Sharma, K. K. Jain, and A. Sharma, "Solar cells: in research and applications-a review," Materials Sciences and Applications, vol. 06, no. 12, pp. 1145-1155, 2015.

[4] G. Niu, X. Guo, and L. Wang, "Review of recent progress in chemical stability of perovskite solar cells," Journal of Materials Chemistry A, vol. 3, no. 17, pp. 8970-8980, 2015.

[5] http://pveducation.com/.

[6] National Center for Biotechnology Information, PubChem Compound Database, CID=123591, https://pubchem.ncbi.nlm .nih.gov/compound/123591.

[7] National Center for Biotechnology Information, PubChem Compound Database; CID=6809, https://pubchem.ncbi.nlm .nih.gov/compound/6809.

[8] Bryan Derksen, wikipedia.

[9] NREL, http://www.nrel.gov/ncpv/.

[10] C. Eames, J. M. Frost, P. R. F. Barnes, B. C. O’Regan, A. Walsh, and M. Saiful Islam, "Ionic transport in hybrid lead iodide perovskite solar cells," Nature Communications, vol. 6, article 7497, 2015.

[11] H. Spanggaard and F. C. Krebs, "A brief history of the development of organic and polymeric photovoltaics," Solar Energy Materials \& Solar Cells, vol. 83, no. 2-3, pp. 125-146, 2004.

[12] H. Hoppe and N. S. Sariciftci, "Organic solar cells: an overview," Journal of Materials Research, vol. 19, no. 7, pp. 1924-1945, 2004.

[13] J. C. Bernède, "Organic photovoltaic cells: history, principle and techniques," Journal of Chilean Chemical Society, vol. 53, no. 3, pp. 1549-1564, 2008.

[14] Z. He, C. Zhong, S. Su, M. Xu, H. Wu, and Y. Cao, "Enhanced power-conversion efficiency in polymer solar cells using an inverted device structure," Nature Photonics, vol. 6, no. 9, pp. 591-595, 2012.

[15] C. E. Small, S. Chen, J. Subbiah et al., "High-efficiency inverted dithienogermole-thienopyrrolodione-based polymer solar cells," Nature Photonics, vol. 6, no. 2, pp. 115-120, 2012.

[16] Z. Tan, W. Zhang, Z. Zhang et al., "High-performance inverted polymer solar cells with solution-processed titanium chelate as electron-collecting layer on ITO electrode," Advanced Materials, vol. 24, no. 11, pp. 1476-1481, 2012.

[17] H. Zhou, L. Yang, A. C. Stuart, S. C. Price, S. Liu, and W. You, "Development of fluorinated benzothiadiazole as a structural unit for a polymer solar cell of 7\% efficiency," Angewandte Chemie International Edition, vol. 50, no. 13, pp. 2995-2998, 2011.

[18] K. M. O’Malley, C.-Z. Li, H.-L. Yip, and A. K.-Y. Jen, "Enhanced open-circuit voltage in high performance polymer/fullerene bulk-heterojunction solar cells by cathode modification with a $\mathrm{C}_{60}$ surfactant," Advanced Energy Materials, vol. 2, no. 1, pp. 8286, 2012.
[19] B. Shin, O. Gunawan, Y. Zhu, N. A. Bojarczuk, S. J. Chey, and S. Guha, "Thin film solar cell with $8.4 \%$ power conversion efficiency using an earth-abundant $\mathrm{Cu}_{2} \mathrm{ZnSnS}_{4}$ absorber," Progress in Photovoltaics: Research and Applications, vol. 21, no. 1, pp. 72 76, 2013.

[20] H. Katagiri, K. Jimbo, S. Yamada et al., "Enhanced conversion efficiencies of $\mathrm{Cu}_{2} \mathrm{ZnSnS}_{4}$-based thin film solar cells by using preferential etching technique," Applied Physics Express, vol. 1, no. $4,2008$.

[21] S. Ahmed, K. B. Reuter, O. Gunawan, L. Guo, L. T. Romankiw, and H. Deligianni, "A high efficiency electrodeposited $\mathrm{Cu}_{2} \mathrm{ZnSnS}_{4}$ solar cell," Advanced Energy Materials, vol. 2, no. 2, pp. 253-259, 2012.

[22] K. Maeda, K. Tanaka, Y. Fukui, and H. Uchiki, "Influence of $\mathrm{H}_{2} \mathrm{~S}$ concentration on the properties of $\mathrm{Cu}_{2} \mathrm{ZnSnS}_{4}$ thin films and solar cells prepared by sol-gel sulfurization," Solar Energy Materials and Solar Cells, vol. 95, no. 10, pp. 2855-2860, 2011.

[23] A. V. Moholkar, S. S. Shinde, A. R. Babar et al., "Synthesis and characterization of $\mathrm{Cu}_{2} \mathrm{ZnSnS}_{4}$ thin films grown by PLD: solar cells," Journal of Alloys and Compounds, vol. 509, no. 27, pp. 7439-7446, 2011.

[24] J. Burschka, N. Pellet, S.-J. Moon et al., "Sequential deposition as a route to high-performance perovskite-sensitized solar cells," Nature, vol. 499, no. 7458, pp. 316-319, 2013.

[25] H. Zhou, Q. Chen, G. Li et al., "Interface engineering of highly efficient perovskite solar cells," Science, vol. 345, no. 6196, pp. 542-546, 2014.

[26] P. Qin, S. Tanaka, S. Ito et al., "Inorganic hole conductorbased lead halide perovskite solar cells with $12.4 \%$ conversion efficiency," Nature Communications, vol. 5, article 3834, 2014.

[27] S. Chavhan, O. Miguel, H.-J. Grande et al., "Organo-metal halide perovskite-based solar cells with $\mathrm{CuSCN}$ as the inorganic hole selective contact," Journal of Materials Chemistry A, vol. 2, no. 32, pp. 12754-12760, 2014.

[28] Z. Wu, S. Bai, J. Xiang et al., "Efficient planar heterojunction perovskite solar cells employing graphene oxide as hole conductor," Nanoscale, vol. 6, no. 18, pp. 10505-10510, 2014.

[29] J. H. Heo, S. H. Im, J. H. Noh et al., "Efficient inorganicorganic hybrid heterojunction solar cells containing perovskite compound and polymeric hole conductors," Nature Photonics, vol. 7, no. 6, pp. 486-491, 2013.

[30] M. A. Green, K. Emery, Y. Hishikawa, W. Warta, and E. D. Dunlop, "Solar cell efficiency tables (version 46)," Progress in Photovoltaics: Research and Applications, vol. 23, no. 7, pp. 805812, 2015

[31] M. Hosoya, H. Oooka, H. Nakao et al., "Organic thin film photovoltaic modules," in Proceedings of the 93rd Annual Meeting of the Chemical Society of Japan, pp. 21-37, 2013.

[32] J. Yan, Q. Wang, T. Wei, and Z. Fan, "Recent advances in design and fabrication of electrochemical supercapacitors with high energy densities," Advanced Energy Materials, vol. 4, no. 4, Article ID 1300816, 2014.

[33] S. Tajima, T. Itoh, H. Hazama, K. Ohishi, and R. Asahi, "Improvement of the open-circuit voltage of $\mathrm{Cu}_{2} \mathrm{ZnSnS}_{4}$ cells using a two-layered process," in Proceedings of the IEEE 40th Photovoltaic Specialist Conference (PVSC '14), pp. 431-434, Denver, Colo, USA, June 2014.

[34] W. S. Yang, J. H. Noh, N. J. Jeon et al., "High-performance photovoltaic perovskite layers fabricated through intramolecular exchange," Science, vol. 348, no. 6240, pp. 1234-1237, 2015.

[35] http://www.nims.go.jp/eng/news/press/2015/06/201506170 .html. 
[36] N. Kaur, M. Singh, D. Pathak, T. Wagner, and J. M. Nunzi, "Organic materials for photovoltaic applications: review and mechanism," Synthetic Metals, vol. 190, pp. 20-26, 2014.

[37] J. Xue, S. Uchida, B. P. Rand, and S. R. Forrest, “4.2\% efficient organic photovoltaic cells with low series resistances," Applied Physics Letters, vol. 84, no. 16, pp. 3013-3015, 2004.

[38] J. G. Xue, S. Uchida, B. P. Rand, and S. R. Forrest, "Asymmetric tandem organic photovoltaic cells with hybrid planar-mixed molecular heterojunctions," Applied Physics Letters, vol. 85, no. 23, pp. 5757-5759, 2004.

[39] T. Ameri, P. Khoram, J. Min, and C. J. Brabec, "Organic ternary solar cells: a review," Advanced Materials, vol. 25, no. 31, pp. 4245-4266, 2013.

[40] J.-M. Nunzi, "Organic photovoltaic materials and devices," Comptes Rendus Physique, vol. 3, no. 4, pp. 523-542, 2002.

[41] K. L. Mutolo, E. I. Mayo, B. P. Rand, S. R. Forrest, and M. E. Thompson, "Enhanced open-circuit voltage in subphthalocyanine/ $\mathrm{C}_{60}$ organic photovoltaic cells," Journal of the American Chemical Society, vol. 128, no. 25, pp. 8108-8109, 2006.

[42] Y. Li and Y. Zou, "Conjugated polymer photovoltaic materials with broad absorption band and high charge carrier mobility," Advanced Materials, vol. 20, no. 15, pp. 2952-2958, 2008.

[43] J. Hou, M.-H. Park, S. Zhang et al., "Bandgap and molecular energy level control of conjugated polymer photovoltaic materials based on benzo[1,2-b:4,5-b/] dithiophene," Macromolecules, vol. 41, no. 16, pp. 6012-6018, 2008.

[44] M. Zhang, X. Guo, Z.-G. Zhang, and Y. Li, "D-A copolymers based on dithienosilole and phthalimide for photovoltaic materials," Polymer, vol. 52, no. 24, pp. 5464-5470, 2011.

[45] J.-F. Nierengarten, T. Gu, G. Hadziioannou, D. Tsamouras, and V. Krasnikov, "A new iterative approach for the synthesis of oligo(phenyleneethynediyl) derivatives and its application for the preparation of fullerene-oligo(phenyleneethynediyl) conjugates as active photovoltaic materials," Helvetica Chimica Acta, vol. 87, no. 11, pp. 2948-2966, 2004.

[46] M. Edoff, "Thin film solar cells: research in an industrial perspective," $A M B I O$, vol. 41, no. 2, pp. 112-118, 2012.

[47] M. Jiang and $\mathrm{X}$. Yan, " $\mathrm{Cu}_{2} \mathrm{ZnSnS}_{4}$ thin film solar cells: present status and future prospects," in Solar Cells-Research and Application Perspectives, A. Morales-Acevedo, Ed., chapter 5, InTech, Rijeka, Croatia, 2013.

[48] G. Altamura, "Development of CZTSSe thin films based solar cells," Material Chemistry, Université Joseph-Fourier-Grenoble I, 2014.

[49] P. Zawadzki, L. L. Baranowski, H. Peng et al., "Evaluation of photovoltaic materials within the Cu-Sn-S family," Applied Physics Letters, vol. 103, no. 25, Article ID 253902, 2013.

[50] I. Grinberg, D. Vincent West, M. Torres et al., "Perovskite oxides for visible-light-absorbing ferroelectric and photovoltaic materials," Nature, vol. 503, no. 7477, pp. 509-512, 2013.

[51] J. Bisquert, "The swift surge of perovskite photovoltaics," The Journal of Physical Chemistry Letters, vol. 4, no. 15, pp. 25972598, 2013.

[52] A. Kojima, K. Teshima, Y. Shirai, and T. Miyasaka, "Organometal halide perovskites as visible-light sensitizers for photovoltaic cells," Journal of the American Chemical Society, vol. 131, no. 17, pp. 6050-6051, 2009.

[53] T. Salim, S. Sun, Y. Abe, A. Krishna, A. C. Grimsdale, and Y. M. Lam, "Perovskite-based solar cells: impact of morphology and device architecture on device performance," Journal of Materials Chemistry A, vol. 3, no. 17, pp. 8943-8969, 2015.
[54] M. A. Green, A. Ho-Baillie, and H. J. Snaith, "The emergence of perovskite solar cells," Nature Photonics, vol. 8, no. 7, pp. 506514, 2014.

[55] M. I. El-Henawey, R. S. Gebhardt, M. M. El-Tonsy, and S. Chaudhary, "Organic solvent vapor treatment of lead iodide layers in the two-step sequential deposition of $\mathrm{CH}_{3} \mathrm{NH}_{3} \mathrm{PbI}_{3}$ based perovskite solar cells," Journal of Materials Chemistry A, vol. 4, no. 5, pp. 1947-1952, 2016. 

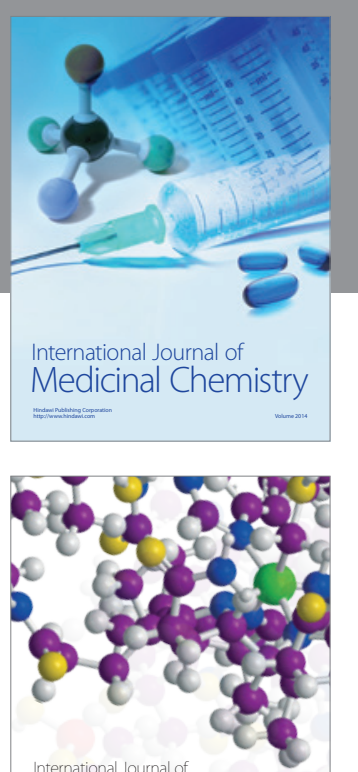

Carbohydrate Chemistry

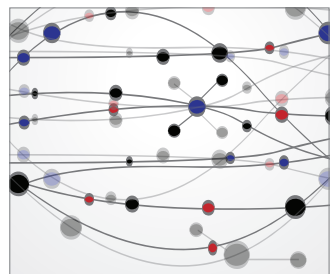

The Scientific World Journal
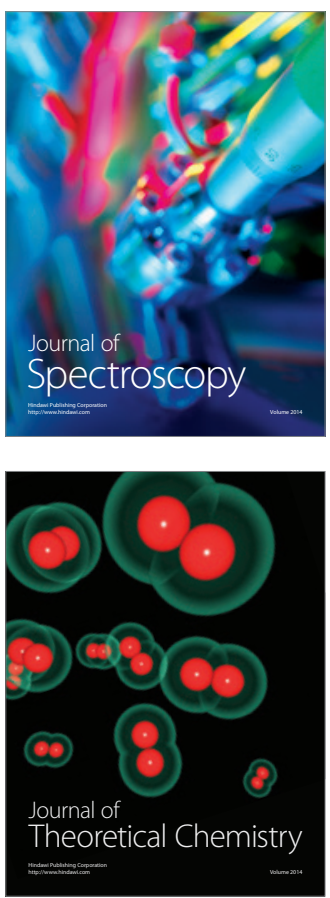
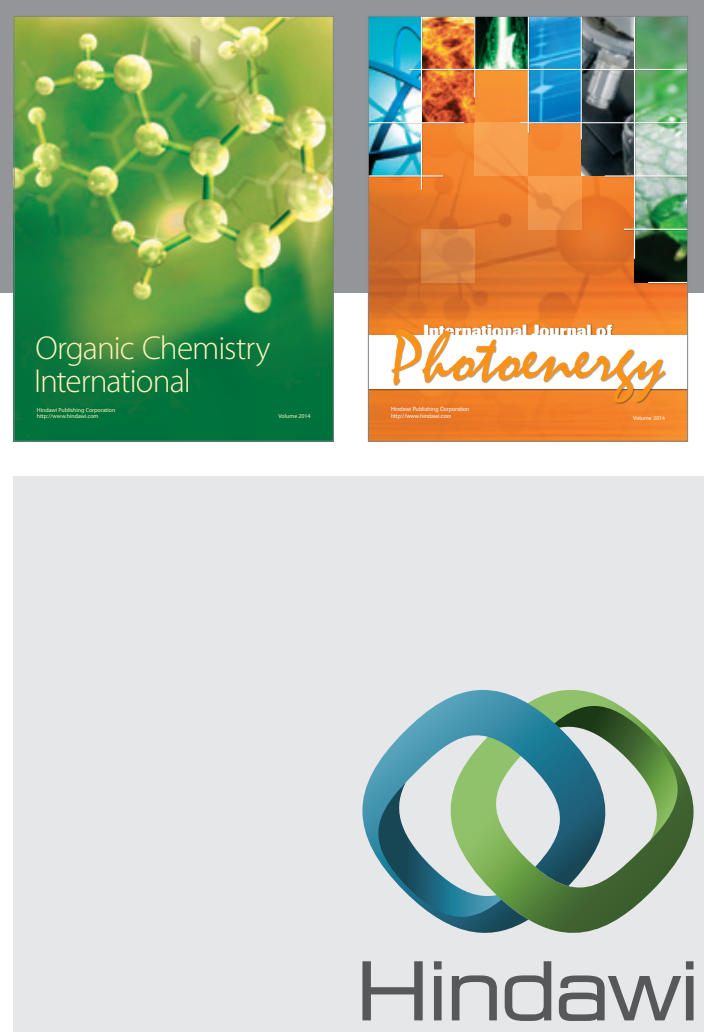

Submit your manuscripts at

http://www.hindawi.com

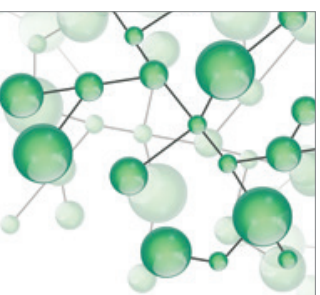

International Journal of

Inorganic Chemistry

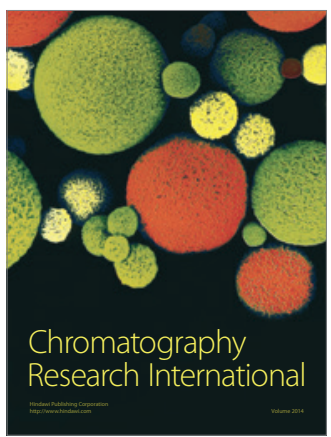

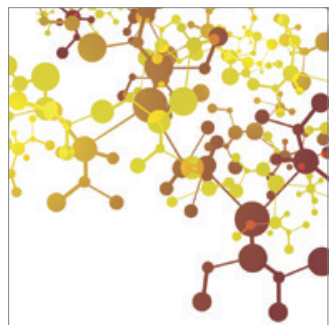

Applied Chemistry
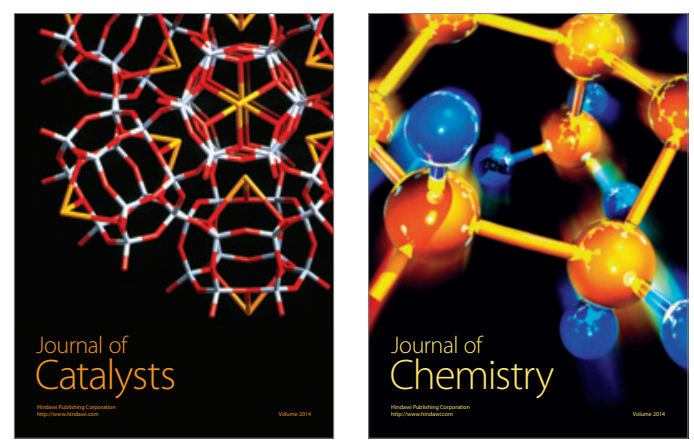
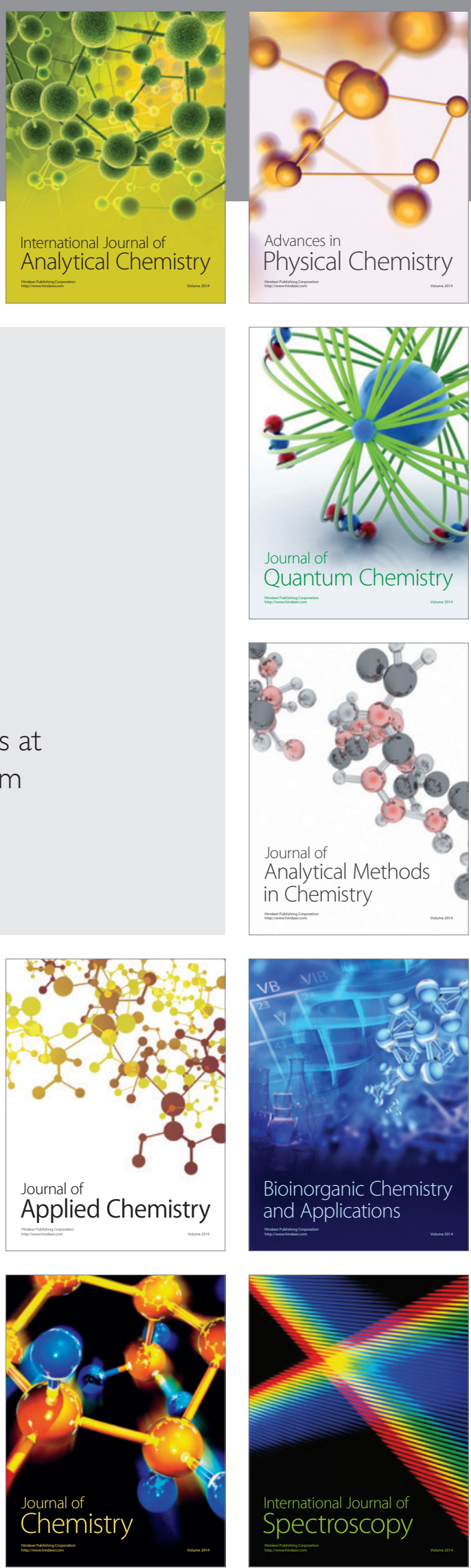